\title{
STANDARDIZATION OF THE WASSERMANN TEST USING PRESERVED COMPLEMENT TITRATED TO 50 PER CENT. HAEMOLYSIS*
}

BY

\author{
P. N. COLEMAN
}

\author{
Central Clinical Laboratory, General Hospital, Middlesbrough
}

This paper describes a modification of the Wassermann test giving an improved standardization of the complement titration and of the haemolytic system which is suitable to the resources of a small laboratory. Advantage has been taken of the stability of complement preserved by the method of Richardson (1941), so that modern methods for the standardization of the haemolytic system can be included in the routine without sacrifice of simplicity in technique.

The improved methods that have been advocated for the titration of complement and the standardization of the haemolytic system may be briefly reviewed. Increased accuracy is obtained in the complement titration by the determination of the point of $\mathbf{5 0}$ per cent. haemolysis rather than that of the minimum haemolytic dose (MHD), giving 100 per cent. haemolysis. The curve of haemolysis is a sigmoid one, and at the point of 50 per cent. haemolysis the rate of change of the degree of haemolysis for a given small change in the amount of complement employed is maximal, whereas at the 100 per cent. point it is minimal. Further accuracy can be obtained by photometric determination of the degree of haemolysis in all tubes of the titration showing partial haemolysis. By mathematical analysis or graphical construction, all the measurements can contribute to the determination of the 50 per cent. point (Kent, Bukantz, and Rein 1946; Mayer, Eaton, and Heidelberger, 1946).

Some authorities consider that the employment of a more accurate method for the complement titration should be accompanied by a similar increase in accuracy of the amboceptor titration. Thus Whillans (1950) employs an amboceptor titration similar to the simple method of Wyler (1929), but measures the degree of haemolysis in the tubes showing partial haemolysis and constructs a graph from the results. Wadsworth (1947a) employs a different and more logical principle. A series of * Received for publication May 19, 1952. parallel complement titrations are carried out using sheep cells sensitized by increasing amounts of amboceptor. It is found that the amount of complement required for 50 per cent. haemolysis decreases as the amount of amboceptor used to sensitize the cells is increased up to a certain critical amount. Further increase of the amount of amboceptor beyond the critical point brings about no further decrease in the amount of complement required for 50 per cent. haemolysis. Amounts of amboceptor equivalent to the critical value are used to sensitize the cells in the Wassermann test.

A more precise complement titration also requires that careful attention shall be given to the possibility of variations in the behaviour of the sheep-cell suspension. Quite considerable differences can be observed in the facility with which different batches of sheep cells can undergo haemolysis by complement and amboceptor. The use of preservatives such as formalin must also be considered, since injury is done to the cells so that they become more susceptible to haemolysis (Eagle, 1937a). It is clear that if the sheep-cell suspension against which complement is being standardized can itself vary from day to day in an unknown manner, increased precision in the complement titration is a useless refinement. Methods are described for obtaining uniformity of behaviour from the sheep cells. The cells used should be restricted to those obtained from specially selected animals which are maintained in the laboratory. The sheep are bled into glucosecitrate, using full aseptic precautions, no preservative being added (Kent, Bukantz, and Rein, 1946; Wadsworth, 1947b).

The techniques described above cannot readily be included in the routine of a small Wassermann laboratory. The time available for the test is limited and the delay occasioned by working out the more complicated titrations, before beginning the test proper is a serious disadvantage. Moreover, in a small laboratory, sheep's blood must be obtained 
from commercial sources, since it is neither economical nor practical to maintain and bleed sheep in the laboratory.

In the method to be described the difficulties have been overcome by the use of preserved complement. Hoyle (1948) gives an indication of the use of preserved complement in this way. He describes a complement-fixation test for influenza, in which preserved complement is titrated to $\mathbf{5 0}$ per cent. haemolysis, and advises that, once a figure for the titre of a batch of preserved complement has been established, it should be adhered to in making up the dose of complement for the first part of the test. Any small variations subsequently observed in the titre should be attributed to variations in the sensitized sheep cells rather than to changes in the complement and should be ignored.

The modification of the Wassermann test here described represents an elaboration of this principle. Experiments confirm that the activity of Richardson's preserved complement remains stable for many weeks, and show that it is possible to carry out the Wassermann test using a predetermined dose of complement at the fixation stage, making no adjustment to meet small day-to-day variations in the behaviour of the sensitized sheep cells. It thus becomes possible to determine the titre of a batch of preserved complement as an experiment separated from the daily Wassermann routine. This titre is at once available on the day that the Wassermann test is to be carried out and no delay is occasioned in beginning the test proper. Since no adjustment is made in the complement dose to fit individual batches of sensitized cells, special precautions to ensure absolutely uniform behaviour from each batch may be omitted. It is necessary however to ensure than an abnormally fragile or resistant batch of cells is not used in the initial determination of the titre of a new batch of complement. This may be done by establishing the titre from the average of the results of a number of complement titrations using different batches of cells. It was not found necessary to adopt an elaborate amboceptor titration. Preliminary experiments showed that, provided that the amboceptor was used in adequate quantities, small variations in the amounts used to sensitize the cells had no significant effect on the results of the complement titration or on the behaviour of the indicator system in the Wassermann test.

\section{Experimental Basis of Method}

Before the details of the modified Wassermann test are described, certain preliminary experiments which formed the basis of the method will be discussed. The following problems were studied experimentally :

(1) the simple amboceptor titration of Wyler (1929) compared with the more elaborate Wadsworth method;

(2) the stability of Richardson's preserved complement over a period of time ;

(3) the effect upon the complement titre and upon the Wassermann test proper of variations in the behaviour of the sensitized sheep cells.

\section{A. Reagents}

(1) Sheep Cells.-The standard reagent used in the routine Wassermann test was defibrinated sheep's blood with added $0 \cdot 1$ per cent. formalin.* This was compared in experimental titrations with blood containing no added preservative.

(2) Preserved Complement.-Complement preserved by Richardson's method was obtained in quantities of 50-75 ml. sufficient for 4 or 5 weeks of routine testing. ?

(3) Amboceptor.-Glycerinated horse v. sheep haemolytic serum. $\ddagger$ in 10-ml. quantities.

(4) Saline. -0.85 per cent. saline is buffered to a $p H$ of 7.3 by sodium and potassium phosphate. A stock solution containing 170.0 g. $\mathrm{NaCl}, 2.78$ g. $\mathrm{K} \mathrm{H}_{2} \mathrm{PO}_{4}$, and $11.3 \mathrm{~g} . \mathrm{Na}_{2} \mathrm{H} \mathrm{PO}_{4}$ to $1 \mathrm{l}$. is diluted for use 1 in 20 (Kent, Bukantz, and Rein, 1946).

\section{B. Methods}

(1) Fairbrother and Maddocks Wassermann Technique. - The experiments and modified method to be described conformed to the principles of the Fairbrother and Maddocks method already in use in the laboratory (Fairbrother, 1942); details of the local modification used are set out below, but attention may be drawn at this stage to certain features. An unusually strong concentration of cells is employed and the long period of 1 hour is allowed at the stage of haemolysis. Final readings of the test proper are made after overnight sedimentation of the cells. Quantitative results are obtained by maintaining a fixed dose of complement and using increasing dilutions of the patient's serum.

It would be out of place here to make comparisons with other methods, but it may be said that the practice of allowing sedimentation of the cells before reading makes for standardization of the results. The distinction is clear between a tube showing the "Positive" result with complete absence of haemolysis in the supernatant, and a tube where inhibition of haemolysis is incomplete. This distinction is not always so easily made when the tubes are examined with the cells suspended. The

\footnotetext{
* Obtained each week from Messrs. Burroughs Wellcome.

† The complement was either prepared from locally obtained guinea-pig serum, or obtained from the Venereal Diseases Reference Laboratory or Messrs. Burroughs Wellcome. All samples gave equally good results.

‡ From Messrs. Burroughs Wellcome.
} 
strong cell suspension ensures that the test is not made insensitive by the long period allowed for haemolysis, and the wide range of colour in the region of partial haemolysis also makes for easy reading.

The Fairbrother and Maddocks technique employs five standard volumes $(0.25 \mathrm{ml}$. in this laboratory) : one vol. of each reagent, sheep cell suspension, $5 \mathrm{MHD}$ amboceptor, 3 MHD complement, antigen dilution, and dilution of patients' serum. In complement and amboceptor titrations the final volume is maintained at five standard volumes by the inclusion of two vol. saline in place of antigen and patient's serum. The sheep-cell suspension is standardized photometrically to a haemoglobin content of 15 per cent. Haldane ( $2 \cdot 2 \mathrm{~g}$. per cent.). This represents approximately a 10 per cent. suspension of packed cells.

(2) Method of Expressing Complement and Amboceptor Quantities.-The amounts of amboceptor and complement used are expressed in one of two ways :

(a) as a fraction indicating the dilution of the reagent in the standard volume (e.g. 1/50 complement meaning 1 in 50,50 being the dilution factor),

(b) in arbitrary units proportional to the actual quantities of horse or guinea-pig serum used.

The unit adopted was one thousand times the reciprocal of the dilution factor (thus $1 / 50$ complement represents 20 units) since the standard volume was $0.25 \mathrm{ml}$., 1 unit represents $0.00025 \mathrm{ml}$. serum.

(3) Complement Titrations.-The complement titrations were carried out to determine the point of 50 per cent. haemolysis by the method of Mayer, Eaton, and Heidelberger (1946). The relation between the degree of haemolysis and the amount of complement used is expressed by the formula attributed to Von Krogh :

$$
\log x=K+1 / n \log \left(\frac{y}{1-y}\right)
$$

$K$ and $n$ are constants, $x$ represents the amount of complement used, and $y$ the degree of haemolysis (100 $y=$ per cent. haemolysis). The equation represents a straight line of slope $1 / n$, the value of $x$ where $\log \frac{y}{1-y}=0$ corresponds to the 50 per cent. point. A complement titration was set up in the usual manner. After removal from the $37^{\circ} \mathrm{C}$. bath, the tubes were centrifuged (or the cells allowed to sediment, see below) and the optical densities of the supernatant fluid from the tubes showing partial haemolysis were measured in a photo-electric colorimeter. A reading for 100 per cent. haemolysis was also obtained. Values of $\log x$ were plotted against $\log \frac{y}{1-y}$.

The value of $x$ is expressed in units of complement. (1000 $\times$ reciprocal of dilution factors). The value of $\log \frac{y}{1-y}$ can be obtained directly from the colorimeter readings, assuming that there is a linear relation between the haemoglobin content of the tubes and the readings of the colorimeter. If $a$ is the reading for 100 per cent. haemolysis, and $r$ is the reading for the particular tube under consideration, then :

$$
\log \frac{v}{1-y}=\log r-\log (a-r) .
$$

Values of $\log x$ are plotted against values of $2-\log$ $\frac{y}{1-y}$ ( 2 being added to avoid negative quantities) and the best straight line is fitted. The value of $\log x$ where $2+\log \frac{y}{1-y}=2$ corresponds to the 50 per cent. point.

Dilutions of complement prepared were $1 / 30,1 / 35$, $1 / 40,1 / 45,1 / 50,1 / 60,1 / 70,1 / 80,1 / 100,1 / 120,1 / 160$, and $1 / 200$. A complement titration was set up and after haemolysis for 1 hour in the $37^{\circ} \mathrm{C}$. bath, the tubes wero placed in the refrigerator and allowed to sediment overnight. The next morning $0.8 \mathrm{ml}$. of the supernatant fluid was withdrawn from all tubes showing partial haemolysis and was placed in a corresponding semimicro tube of an EEL photo-electric colorimeter, 3.0 ml. water containing 0.04 per cent. ammonia being added to each of the EEL tubes. The reading for 100 per cent. haemolysis was obtained by using $0.8 \mathrm{ml}$. of the mixed contents of the tubes showing complete haemolysis. A blank containing one vol. saline in place of the complement dilution was taken through with the complement titration, and $0.8 \mathrm{ml}$. of the supernatant diluted with $3.0 \mathrm{ml}$. water with 0.04 per cent. ammonia was used to zero the colorimeter. Readings were made using the green filter.

The procedure of allowing overnight sedimentation of the cells before reading the complement titration rather than immediate centrifuging of the tubes after 1 hour in the $37^{\circ} \mathrm{C}$. bath, was adopted to minimize labour in the large numbers of titrations carried out. Preliminary experiments were undertaken in which the two procedures were compared by parallel complement titrations. It was found that the relatively long period in the $37^{\circ} \mathrm{C}$. bath allows haemolysis to proceed almost to completion, and essentially similar results were obtained by both methods, a very small additional degree of haemolysis occurring during the night.

For titrations carried out as part of the Wassermann technique to be described, the tubes are centrifuged as soon as they have been taken from the $37^{\circ} \mathrm{C}$. bath. It also makes for ease in pipetting the supernatant, if the standard volume for the complement titration is doubled to $0.5 \mathrm{ml}$; $1.0 \mathrm{ml}$. of the supernatant can then be removed to EEL semi-micro tubes, which are then made up with $3.0 \mathrm{ml}$. water containing 0.04\% ammonia.

\section{(4) Amboceptor Titrations}

WYLER'S METHOD.-A series of increasing dilutions of amboceptor are prepared;1/200,1/400,1/600, to $1 / 2000$. A set of tubes are put up and one volume of the amboceptor dilution is placed in the appropriate tube. To each tube is added one vol. cell suspension. After $\frac{1}{2}$ hour on the bench for sensitization, one vol. 1/10 complement and two vols. saline are added to each tube. Haemolysis is allowed to take place for 1 hour in the $37^{\circ} \mathrm{C}$. bath, and the MHD is then determined. 
WADSWORTH's METHOD. $-4 \mathrm{ml}$. quantities of a single batch of sheep cells were sensitized by equal volumes of a series of eight amboceptor dilutions increasing from 0.6 to 5.0 units of amboceptor in each standard volume by equal increments of 0.65 units. A series of parallel complement titrations were carried out, and the value of $x$ for 50 per cent. haemolysis and of the slope $1 / n$ for each titration determined.

(5) Experimental Wassermann Titrations.-The effect upon the results of the Wassermann test of maintaining a fixed dose of complement at the fixation stage and not making allowance for variation in the sensitized cells was studied by parallel Wassermann titrations upon single samples of "Positive" sera. Variations in the behaviour of the cell suspension were obtained by employing different quantities of the same cell suspension or by comparing formalized cells with cells without added preservative.

\section{Results}

(1) Amboceptor Titrations.-During a period of one month a series of sets of amboceptor titrations was carried out using the same sample of amboceptor and preserved complement throughout. A different sample of sheep cells was used for each set of titrations. Both formalized cells and cells without added preservatives were used, and the formalized cells were used both on receipt and after being kept in the laboratory for one week. Each set of titrations consisted of a titration by Wyler's method and the eight parallel complement titrations using cells sensitized by increasing quantities of amboceptor which make up the Wadsworth titration already described. The results are shown in Table I.

Table I shows that, as described by Wadsworth, the use of an increased amount of amboceptor to sensitize the cells brings about a decrease in the amount of complement required for 50 per cent. haemolysis up to a certain critical value for the amount of amboceptor. Beyond that a further increase in amboceptor is not accompanied by any further decrease in the complement required for 50 per cent. haemolysis. Amounts of amboceptor equivalent to the critical value described above were used by Wadsworth to sensitize the cells for the Wassermann test. The slope of the straight line obtained in the logarithmic plot of the complement titration $(1 / n)$ also shows a decrease in value with increasing amounts of amboceptor up to the critical value. Beyond the critical value, no further change is seen in $1 / n$ when larger quantities of amboceptor are used. Table I shows that, provided a certain minimum adequate quantity is used, the actual amounts of amboceptor can be varied within fairly wide limits without bringing about an appreciable change in the amount of complement required for 50 per cent haemolysis or in the $1 / n$ value. In deciding the amount of

TABLE I

EFFECT OF AMOUNT OF AMBOCEPTOR ON COMPLEMENT TITRATION

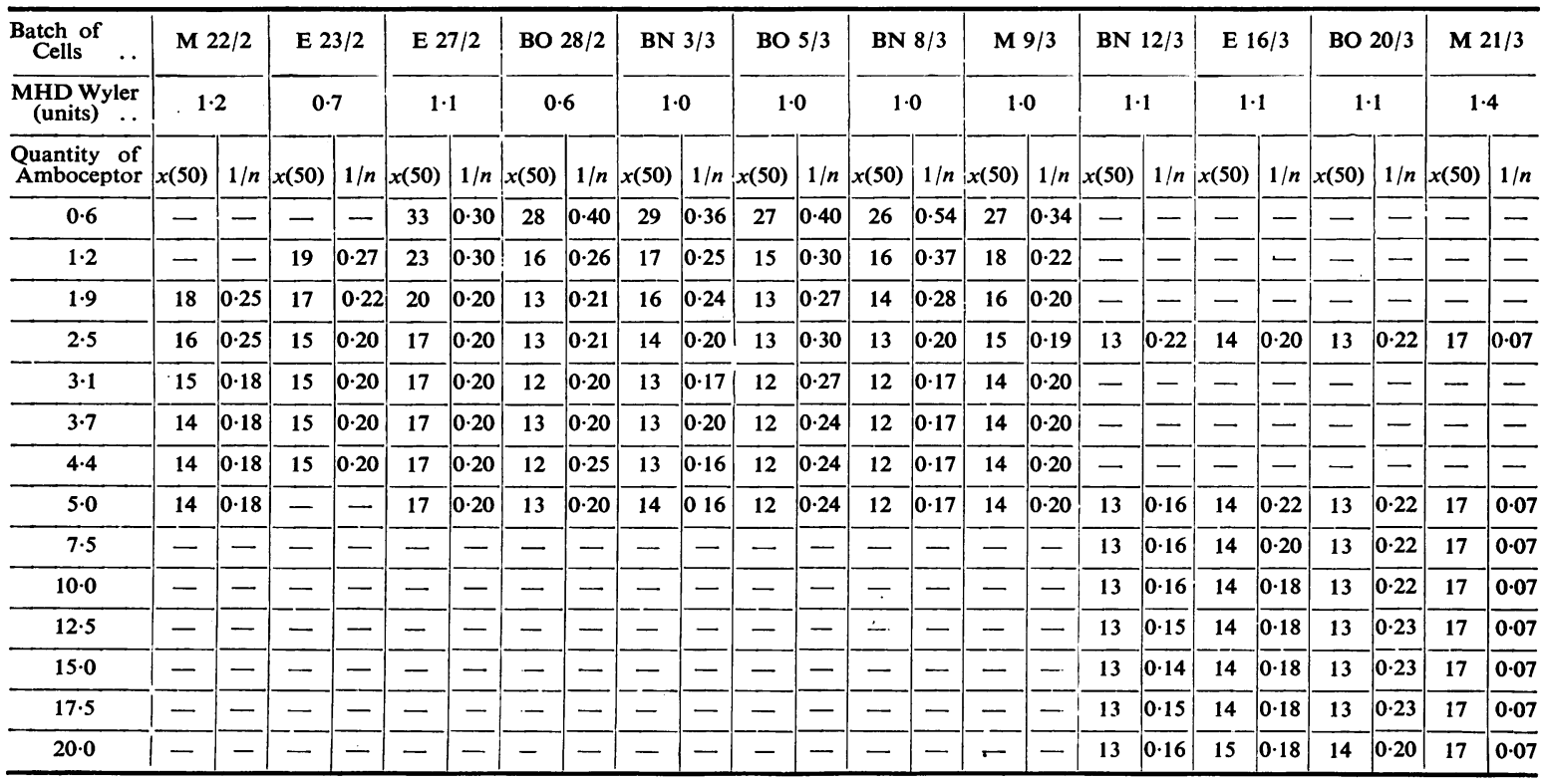

Same batch of haemolytic serum and preserved complement used in all experiments.

Quantities of amboceptor and complement used are expressed in units given by $1000 \times$ reciprocal of dilution $($ e.g., $1 / 50=20$ units). $x(50)$ is the amount of complement required for 50 per cent. haemolysis. $1 / n$ is the slope of the fitted straight line in the logarithmic plot of the complement titration. In the last four experiments, increased quantities of amboceptor were employed to determine whether relative amboceptor excess would result in a fall of complement titre or a change in $1 / n$. No such effect was observed. 
amboceptor to be used in the Wassermann test, sufficient accuracy will therefore be obtained by employing a simple titration method that will ensure that the amounts used are adequate. The simple method of amboceptor titration carried out at infrequent intervals as recommended by Wyler (1929) may therefore be employed. The Wadsworth critical values, as determined from Table I, are about 2 MHD Wyler. If 5 MHD amboceptor is used to sensitize the cells, there will be a margin of safety which will allow for any slight deterioration of the amboceptor with age and for variation in the amboceptor requirements of different batches of cells.

(2) Stability of Richardson's Preserved Complement.Complement preserved by Richardson's method is said to show no noticeable loss of titre until after 6 to 9 months. (Mackie and McCartney, 1948). Samples used in this laboratory for the routine Wassermann have always maintained their titre throughout the period of use ( 3 to 6 weeks). The Figure shows the result of a number of titrations on single samples of preserved complement over periods of 5 weeks. There is no evidence of any loss of titre due to ageing, the up and down variations observed being clearly due to variations in the behaviour of the sensitized sheep cells.

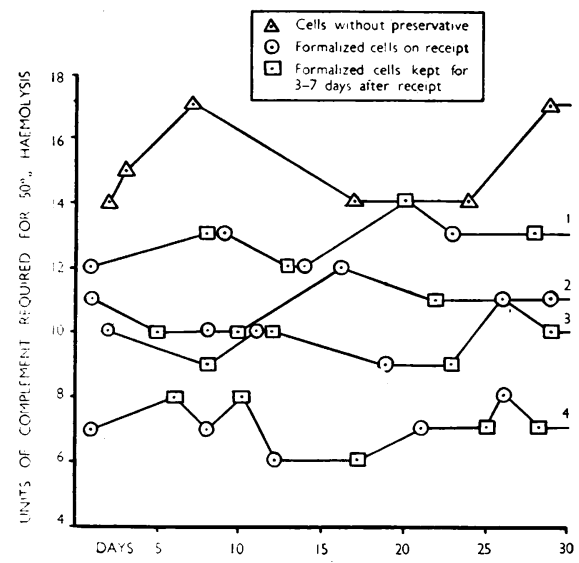

FIGURE.-Variations observed in titres of four batches of preserved complement titrated at intervals during a period of 30 days. No. 1 is the complement referred to in Table II. Nos. 2, 3, and 4 were titrated during a routine Wassermann test.

(3) Variations in Complement Titre due to Cell Suspension.-The Figure shows therefore the extent of the variation that can be introduced into the titration of complement by the use of different batches of sheep cells. Complement 1 shows a range of titres from 12 to 17 units, but if formalized cells and cells without added preservative are considered separately, narrower ranges are found. These are 12 to 14 units and 14 to 17 units respectively. No significant alteration in the behaviour of the formalized cells occurs if they are kept for a week. In the titrations shown for Complements 2,3 , and 4, formalized cells alone were used. The same narrow range of titres ( + or -1 unit) is seen.
The behaviour of cells without added preservative was investigated in additional experiments. Samples of blood from twelve sheep were obtained from the abattoir. Sensitized cell suspensions were prepared, and were compared with a single sample of formalized cells in thirteen parallel complement titrations. This experiment was carried out twice, using the same preserved complement-once within a few hours of obtaining the blood and again after a lapse of 4 days. In the first experiment, the amount of complement required for 50 per cent. haemolysis ranged from 17 to 22 units, and in the second experiment from 13 to 20 units, compared with 12 units required for formalized cells.

Thus in the titration of complement using cells obtained from the abattoir and used between 1 and 4 days of collection, the amount of complement required for 50 per cent. haemolysis was nearly doubled between the most fragile and the most resistant cells encountered.* Using formalized cells from a reliable commercial source, it was found that less complement was required than for any of the samples of cells without added preservative; thus suggesting that the cells were indeed injured in some way by the preservative. However the formalized cells showed a uniformity of behaviour that was entirely adequate for obtaining standard results from the Wassermann test.

(4) Wassermann Test using Fixed Dose of Complement. - It is customary to adjust the dose of complement used in the first part of the Wassermann test to fit the particular suspension that is to be used in the second part. Reference has already been made to Hoyle's suggestion that a fixed dose of preserved complement should be used, no change being made to conform with small dayto-day variations in the behaviour of the sensitized cells. Eagle (1939) used a fixed quantity (1 vol. of a 1/10 dilution) of pooled guinea-pig serum at the fixation stage of the Wassermann. The effect upon the reported results of the Wassermann test by these two methods, complement dose adjusted to cell suspension (Experiment A) and complement dose fixed (Experiment B), are shown in Table II (overleaf).

Using the adjusted dose of complement on the occasional day when the cells are unduly fragile, relatively smaller amounts of complement will be employed and some sera of lower reagin content which would normally be reported as "Doubtful" will be able to fix all the complement offered and will be reported " Positive ". Conversely, if the cells are unduly resistant, sera which would normally be reported as giving an only just " Positive " reaction will be reported as " Doubtful ".

When a fixed dose of complement is used, uniformity in reporting "Positive" sera will be obtained. In a tube showing the "Positive" reaction all the complement has been fixed in the first part of the test, and whether fragile or resistant cells are added no haemolysis can take place in the second part. Differences however, arise in the reporting of sera as "Doubtful ". When a serum of low reagin content is examined, a proportion

\footnotetext{
*In this context the terms "fragile" and " resistant " refer to the relative ease or difficulty with which the cells underwent haemolysis by complement.
} 
TABLE II

EXPERIMENTAL WASSERMANN TITRATIONS

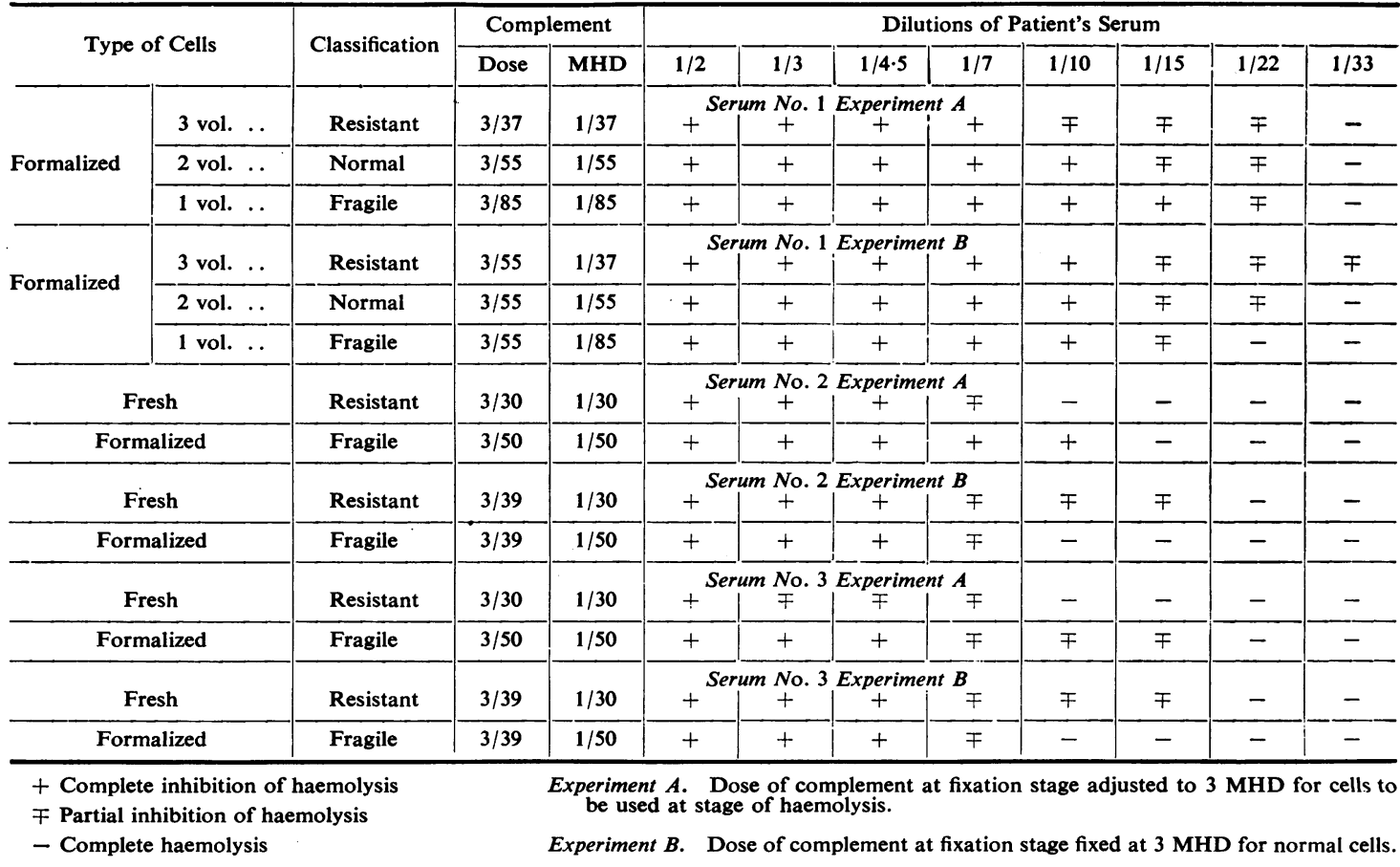

of the complement remains at the end of the period of fixation. If unduly fragile cells are then added, the small quantity of complement remaining may still be sufficient to bring about complete haemolysis and the serum will be reported as "Negative". A method of overcoming this difficulty is described below.

The effect of the two methods of deciding the dose of complement in the Wassermann reaction, dose adjusted to the cell suspension and dose prefixed and not adjusted to the particular cell suspension, was studied experimentally. In some experiments the results from the use of fragile, normal, and resistant cells were simulated by using the same normal cell suspension but adding, one, two, and three volumes of cells. Complement titrations showed that the amount of complement required for 50 per cent. haemolysis when one and three volumes of cells were used, were roughly two-thirds and four-thirds of the amount acquired when the usual two volumes were used. This gave a range similar to that observed between the most fragile and most resistant cells encountered in the previous experiments. In other experiments, fragile cells were compared with resistant cells by comparing a suspension of formalized cells with a suspension of cells freshly obtained from the abattoir.

Parallel titrations of the same "Positive" serum were carried out. In a first set of titrations, the complement dose used at the fixation stage was adjusted to 3 MHD of the cells to be added. In a second set of titrations the complement dose was fixed at 3 MHD for normal cells.
The results shown in Table II confirmed the conclusion reached from theoretical considerations in the preceding paragraphs but the differences observed between the various titrations were not large.

It has already been shown that, when a fixed dose of complement not adjusted to the particular cell suspension is used, certain sera of low reagin content which would normally be reported "Doubtful' will be reported "Negative" if the cell suspension is unduly fragile. A means was sought by which a standard sensitivity in the reporting of "Doubtful" sera could be obtained irrespective of the behaviour of the cell suspension.

It was decided that cells should be classified as fragile or resistant when the amounts of complement required for 50 per cent. haemolysis were found to be $4 / 5$ or less and $6 / 5$ or more of the amount required for 50 per cent. haemolysis using normal cells. This represents a difference in complement requirements between fragile and resistant cells in the proportion of 1 to 1.5 and covers the range observed in the experimental complement titrations. Studies were made of the effects upon the observed titre of a complement titration of

(1) increasing the volume of the sensitized cells added beyond the usual two vols.

(2) maintaining the usual volume of sensitized cells but diluting the sensitized cell suspension with saline before addition.

It was found that, if $0.7 \mathrm{ml}$. sensitized cells was added instead of the usual $0.5 \mathrm{ml}$., the amount of complement 
TABLE III

CONVERSION TABLE FOR USE WITH BURROUGHS WELLCOME FORMALIZED SHEEP'S BLOOD

\begin{tabular}{|c|c|c|c|c|c|c|c|c|c|c|}
\hline \multirow{2}{*}{$\begin{array}{l}\text { Observed } \\
\text { Haemolysis } \\
\text { (per cent.) }\end{array}$} & \multicolumn{10}{|c|}{ Tube } \\
\hline & $1 / 40$ & $1 / 45$ & $1 / 50$ & $1 / 60$ & $1 / 70$ & $1 / 80$ & $1 / 90$ & $1 / 100$ & $1 / 120$ & $1 / 160$ \\
\hline 10 & $39 \cdot 7$ & $35 \cdot 2$ & $32 \cdot 3$ & 26.9 & $22 \cdot 6$ & $19 \cdot 8$ & $17 \cdot 6$ & $15 \cdot 8$ & $13 \cdot 2$ & $11 \cdot 3$ \\
\hline 15 & 35.9 & $32 \cdot 6$ & $29 \cdot 3$ & $24 \cdot 4$ & 20.9 & $18 \cdot 3$ & $16 \cdot 3$ & $14 \cdot 7$ & $12 \cdot 2$ & $11 \cdot 0$ \\
\hline 20 & $32 \cdot 4$ & $30 \cdot 1$ & $27 \cdot 2$ & $22 \cdot 6$ & $19 \cdot 4$ & $16 \cdot 9$ & $15 \cdot 1$ & $13 \cdot 5$ & $11 \cdot 3$ & $9 \cdot 9$ \\
\hline 25 & $31 \cdot 8$ & $28 \cdot 3$ & $25 \cdot 8$ & $21 \cdot 2$ & $18 \cdot 4$ & $15 \cdot 9$ & $14 \cdot 2$ & $12 \cdot 7$ & $10 \cdot 6$ & $9 \cdot 1$ \\
\hline 30 & $30 \cdot 0$ & 26.9 & $24 \cdot 1$ & $20 \cdot 1$ & $17 \cdot 2$ & $15 \cdot 1$ & $13 \cdot 4$ & $12 \cdot 0$ & $10 \cdot 0$ & $8 \cdot 6$ \\
\hline 35 & $28 \cdot 6$ & $25 \cdot 9$ & $22 \cdot 9$ & $19 \cdot 1$ & $16 \cdot 3$ & $14 \cdot 3$ & $12 \cdot 7$ & $11 \cdot 5$ & $9 \cdot 5$ & $8 \cdot 2$ \\
\hline 40 & $27 \cdot 9$ & $24 \cdot 3$ & $21 \cdot 9$ & $18 \cdot 2$ & $15 \cdot 6$ & $13 \cdot 7$ & $12 \cdot 2$ & $10 \cdot 9$ & $9 \cdot 1$ & $7 \cdot 8$ \\
\hline 45 & $26 \cdot 1$ & $23 \cdot 2$ & 20.9 & $17 \cdot 4$ & $14 \cdot 9$ & $13 \cdot 1$ & 11.6 & $10 \cdot 4$ & $8 \cdot 7$ & $7 \cdot 5$ \\
\hline 50 & $25 \cdot 0$ & $22 \cdot 2$ & $20 \cdot 0$ & $16 \cdot 7$ & $14 \cdot 2$ & $12 \cdot 5$ & $11 \cdot 1$ & $10 \cdot 0$ & $8 \cdot 3$ & $7 \cdot 2$ \\
\hline 55 & 23.9 & $21 \cdot 2$ & $19 \cdot 1$ & $16 \cdot 0$ & $13 \cdot 7$ & $12 \cdot 0$ & $10 \cdot 6$ & $9 \cdot 6$ & $8 \cdot 0$ & $6 \cdot 8$ \\
\hline 60 & $22 \cdot 9$ & $20 \cdot 3$ & $18 \cdot 3$ & $15 \cdot 2$ & $13 \cdot 1$ & $11 \cdot 4$ & $10 \cdot 2$ & $9 \cdot 1$ & $7 \cdot 6$ & $6 \cdot 5$ \\
\hline 65 & $21 \cdot 8$ & $19 \cdot 4$ & $17 \cdot 4$ & $14 \cdot 5$ & $12 \cdot 5$ & $10 \cdot 9$ & $9 \cdot 7$ & 8.7 & $7 \cdot 3$ & $6 \cdot 2$ \\
\hline 70 & $20 \cdot 7$ & $18 \cdot 4$ & 16.6 & $13 \cdot 8$ & 11.9 & 10.4 & $9 \cdot 2$ & $8 \cdot 2$ & 6.9 & 5.9 \\
\hline 75 & $19 \cdot 7$ & $17 \cdot 5$ & $15 \cdot 7$ & $13 \cdot 1$ & $11 \cdot 2$ & $9 \cdot 8$ & $8 \cdot 7$ & $7 \cdot 8$ & $6 \cdot 5$ & $5 \cdot 6$ \\
\hline 80 & 18.4 & 16.4 & $14 \cdot 8$ & $12 \cdot 3$ & $10 \cdot 5$ & $9 \cdot 2$ & $8 \cdot 2$ & $7 \cdot 4$ & $6 \cdot 1$ & $5 \cdot 2$ \\
\hline 85 & $17 \cdot 1$ & $15 \cdot 2$ & 13.6 & $11 \cdot 4$ & $9 \cdot 7$ & $8 \cdot 5$ & $7 \cdot 6$ & $6 \cdot 8$ & $5 \cdot 7$ & $4 \cdot 9$ \\
\hline 90 & $15 \cdot 8$ & 14.0 & $12 \cdot 4$ & $10 \cdot 3$ & 9.0 & 7.9 & $7 \cdot 0$ & $6 \cdot 3$ & 5.0 & $4 \cdot 3$ \\
\hline
\end{tabular}

required for 50 per cent. haemolysis was increased in the ratio $4 / 5$ to 1 . Also, maintaining the volume of cells added at the usual $0.5 \mathrm{ml}$., but diluting the sensitized cells with saline in proportion of 3 parts saline to 7 parts cells, the amount of complement required was reduced in the ratio $6 / 5$ to 1 .

The following procedure was adopted to correct cell suspensions classified as fragile or resistant :

For fragile cells $0.7 \mathrm{ml}$. suspension was added instead of $0.5 \mathrm{ml}$.

For resistant cells the suspension was diluted with saline in the proportion of 3 parts saline to 7 parts cells, before adding the usual $0.5 \mathrm{ml}$. suspension.

Experiments using formalized cells and fresh cells without added preservative to represent fragile and resistant cells showed that in Wassermann titrations of positive sera similar results were obtained with both fragile and resistant cells if the procedure was adjusted in the manner described above.

\section{Details of Modified Fairbrother Wassermann}

(1) Reagents (As described in Section 2 above).

Preparation of Sheep Cell Suspension.-An approximate 20 per cent. suspension of the washed cells is prepared and the haemoglobin content measured in the EEL photo-electric colorimeter which has been previously calibrated for this purpose. (Use a 1 in 100 dilution in water with 0.04 per cent. ammonia of the suspension in the standard tube with green filter). The strong suspension is further diluted according to the formula :

Volume of saline to be added $=$ $\frac{\text { Original Volume } \times(\text { Observed } \mathrm{Hb}-15)}{15}$.

(2) Amboceptor Titration.-By Wyler's method (Section 2) carried out each time a new amboceptor is brought into use.

(3) Sensitized Cells.-A dilution of 5 MHD amboceptor is prepared and used to sensitize an equal volume of cell suspension.

(4) Complement Titration.-Details are described in Section 2. In routine work graphical construction can be avoided by use of the following Conversion Table. Table III is calculated from Von Krogh's formula, substituting the value of 0.22 for $1 / n$ (the average value found in many titrations). If $1 / D$ is the dilution of a particular tube in the complement titration and $x(50)$ the amount of complement in units required for 50 per cent. haemolysis, then

$$
\log x(50)=3-\log \mathrm{D}-0.22 \log \left(\frac{y}{1-y}\right) .
$$

Use of Conversion Table.-Note the observed haemolysis in any given tube of the complement titration which shows partial haemolysis. Choosing the column in the conversion table corresponding to the dilution of the tube under consideration, the value of $x(50)$ is opposite the percentage of the observed haemolysis. Thus in a 
given titration the observed haemolysis for the $1 / 60$, $1 / 70,1 / 80$, and $1 / 90$ tubes was found to be $80,65,55$, and 35 per cent. The Conversion Table gives $x(50)$ values of $12 \cdot 3,12 \cdot 5,12 \cdot 0$, and $12 \cdot 7$. The $x(50)$ value for the titration is the average of these readings $(12 \cdot 4)$.

(5) Determination of Average Titre of Complement.-The titre of preserved complement used in making up the dose of complement for the fixation stage of the Wassermann test is that for sensitized cells of average fragility. This may be termed the " averaged titre" of the complement and is determined each time a new batch of complement is brought into use. The new complement is compared with a complement previously in use in a parallel complement titration using any given batch of sensitized cells. The " averaged titre" of the old complement is worked out by averaging the $x(50)$ values of a number of complement titrations, using different batches of cells, that have been recorded during its period of use.

Then the Averaged Titre of New Complement $=$

Observed $x(50)$ New Complement $\times$ Averaged Titre of old Complement

Observed $x(50)$ Old Complement

(6) Dose of Complement for Fixation Stage of Wassermann Test.-In order to retain a direct comparison with the previous method, the dose of complement used at the fixation stage has been retained at 3 MHD. It was found by experiment that the amount of complement required for MHD could be calculated by multiplying the amount required for 50 per cent. haemolysis by $1 \cdot 8$. It is convenient to record on the label of a batch of preserved complement the amount of complement required for 50 per cent. haemolysis expressed in units $x(50)$ and as a dilution $1 / \mathrm{D}(50)$, and also the dilution required for MHD 1/D(100). The quantities all refer to averaged titres and are related as follows :

$$
\begin{aligned}
\mathrm{D}(50) & =1000 \div x(50) \\
\mathrm{D}(100) & =\mathrm{D}(50) \div 1 \cdot 8
\end{aligned}
$$

(7) Purpose of Daily Complement Titration.-A complement titration is carried out each time the Wassermann test is performed. This titration is not required in order to determine the dose of complement to be used at the fixation stage, since the averaged titre which is already known is used for this purpose. The complement titration serves two purposes :

(i) It would not be good practice for the averaged titre of a batch of preserved complement as determined at the beginning of the period of use to be passed on to the next batch of complement by parallel titration, for in this way cumulative errors might build up. Therefore the titre obtained from the titration on each Wassermann day is recorded, so that a new averaged titre can be established from the results at the end of a period.

(ii) The complement titration also serves to classify the cells in use on a particular day as normal, fragile, or resistant. The correction to be applied should cells other than normal be in use has already been indicated (Section 2). The classification is required at an early stage of the day, and for this purpose it is sufficiently accurate for a preliminary reading to be made of the complement titration. The contents of a tube showing 100 per cent. haemolysis are diluted by an equal volume of saline and matched against the supernatant fluid of the tubes showing partial haemolysis. The observed 50 per cent. titre is noted and compared with the " averaged titre" recorded on the label of the preserved complement.

The cells in use are classified* as normal, fragile, or resistant as follows :

Fragile.-Observed titre $=1 / \mathrm{D}(50)$ (averaged) $\times 4 / 5$ or greater dilution.

Resistant .-Observed titre $=1 / \mathrm{D}(50)$ (averaged) $\times 6 / 5$ or lesser dilution.

\section{(8) Test Proper}

1 vol. $1 / 2$ dilution of patient's serum (also $1 / 4,1 / 8$, and $1 / 16$ for quantitative tests).

1 vol. 3 MHD complement.

1 vol. dilute antigen (See Note 1 below).

Fixation for 1 hour in $37^{\circ} \mathrm{C}$. bath.

Addition of 1 vol. sheep cell suspension) mix equal 1 vol. 5 MHD amboceptor $\left\{\begin{array}{l}\text { vols. } \frac{1}{2} \text { hour } \\ \text { before test. }\end{array}\right.$

Haemolysis for 1 hour in $37^{\circ} \mathrm{C}$. bath.

Sedimentation of cells overnight in refrigerator.

Reading of results next day.

Note 1.- The antigen is made up to 1 in 25 of the cholesterized heart extract and diluted by further saline according to the result of a titration carried out by the method of Eagle (1937b) each time a new antigen is brought into use. A final dilution of $1 / 100$ is usually found to be optimum. The proportion of antigen to patient's serum is very similar to the proportions employed in the Richardson modification of the HarrisonWyler Wassermann technique (Richardson, 1940).

Note 2.-A test is described as positive if at a $1 / 2$ dilution of the serum there is complete absence of haemolysis in the supernatant after sedimentation of the cells. A titre $(1 / 2,1 / 4$, etc.) is assigned by noting the highest dilution showing complete absence of haemolysis. If the supernatant of the $1 / 2$ tube shows partial haemolysis the test is reported as "Doubtful".

(9) Screen Test.-A preliminary one-tube screen test omitting the serum control is carried out to exclude sera showing the "Negative" reaction. In this test the standard volume is increased from 0.25 to $0.3 \mathrm{ml}$. so that the half volume of serum may be $0.15 \mathrm{ml}$. and may be pipetted at the same time as the Kahn test. To each tube containing

* Using Burroughs Wellcome cells it is unusual for any classification other than normal to be obtained. 
$0.15 \mathrm{ml}$. patient's serum is added $0.75 \mathrm{ml}$. of a mixture containing two parts dilute antigen, two parts 3 MHD complement, and one part saline. The screen tests should be set up after the complement titration has been in the $37^{\circ} \mathrm{C}$. bath for half an hour. The rack containing the screen test is placed in the $37^{\circ} \mathrm{C}$. bath, and while fixation takes place a preliminary reading is made of the complement titration. The complement titration is removed from the bath after 1 hour of haemolysis and all tubes showing partial haemolysis and the cell control tube are centrifuged (Section 2). The preliminary reading for $\mathbf{5 0}$ per cent. haemolysis is made by comparing a $1 / 2$ dilution of the contents of a tube showing complete haemolysis with the supernatant fluids of the tubes showing partial haemolysis. $1 \mathrm{ml}$. quantities of the supernatant fluids are then removed to a series of appropriately labelled EEL semi-micro tubes which may then be set on one side. The titration is finished as already described at some convenient time later in the day, the final titre for 50 per cent. haemolysis being only required for the record.

The preliminary reading of the complement titration enables the cells in use to be classified as normal, fragile, or resistant (see above). After one hour of fixation sensitized cells are added to the screen tests ; with normal cells, $0.6 \mathrm{ml}$. are added to all tubes, if the cells are classified as fragile $0.85 \mathrm{ml}$. are added, and if resistant $0.6 \mathrm{ml}$. are added, but the sensitized cells are diluted in the proportion seven parts cells to three parts saline before addition. Haemolysis is allowed to continue for 1 hour (if more convenient half an hour will be sufficient for screen tests). All sera showing complete haemolysis are reported as "Negative". Sera showing complete or partial inhibition of haemolysis are reexamined using four dilutions of the serum and a serum control tube.

(10) Re-examination of Presumptive Positive or Doubtful Sera.

The standard volume is $0.25 \mathrm{ml}$.

Set up five tubes for each serum to be tested.

To all tubes add $\mathbf{0 . 2 5} \mathrm{ml}$. saline.

To Tube 1 add $0.25 \mathrm{ml}$. serum, mix, and discard $0.25 \mathrm{ml}$. This is the serum control tube.

To Tube 2 add $0.25 \mathrm{ml}$. serum, mix, and carry over $0.25 \mathrm{ml}$. to Tube 3 ; mix and carry over $0.25 \mathrm{ml}$. to Tube 4 ; mix and carry over $0.25 \mathrm{ml}$. to Tube 5 ; discard 0.25 ml. from Tube 5. This gives $1 / 2,1 / 4,1 / 8$, and $1 / 16$ dilutions of serum.

Prepare a further supply of 3 MHD complement, and set aside sufficient for the serum control tubes $(0.25 \mathrm{ml}$. for each serum tested).

Now prepare a complement/antigen mixture, equal volumes of each reagent. To Tube 1 add $0.25 \mathrm{ml}$. 3 MHD complement and $0.25 \mathrm{ml}$. saline. To all other tubes add $0.5 \mathrm{ml}$. of complement/antigen mixture. Place the tubes in a water bath at $37^{\circ} \mathrm{C}$. for 1 hour and now add sensitized cells. Using normal cells, $0.5 \mathrm{ml}$. sensitized cells are added to all tubes. Using fragile cells, $0.7 \mathrm{ml}$. are added. Using resistant cells, $0.5 \mathrm{ml}$. sensitized cells previously diluted in the proportion seven parts cells to three parts saline are added.

Allow haemolysis to take place for 1 hour in the $37^{\circ} \mathrm{C}$. bath.

Place the racks in the refrigerator and allow the cells to sediment overnight.

Read the results next morning according to the principles described in Note 1 above.

\section{Summary}

A modification of the Fairbrother-Maddocks method for the Wassermann test employing 50 per cent. haemolysis as the end point of the complement titration is described. The titration is carried out photometrically.

The amboceptor titration has been investigated and a corresponding elaboration has been found to be unnecessary.

The use of complement preserved by Richardson's method at a predetermined fixed titre enables standard results to be obtained irrespective of variations in the behaviour of the haemolytic system, and allows the day's tests to be begun without waiting for the working out of the complement titration.

My thanks are due to Dr. L. Maddocks for advice and for the opportunity of learning the details of the Fairbrother-Maddocks Wassermann test, to Dr. Stanley Wray for advice and criticism, and to Mr. W. H. Bound and Mrs. V. Hewison for technical assistance.

\section{REFERENCES}

Eagle, H. (1937a). "The Laboratory Diagnosis of Syphilis", pp. 96-98. Mosby, St. Louis.

-(1937b). Ibid., pp. 69 and 146.

(1939). Vener. Dis. Inform., Suppl. No. 9.

Fairbrother, R. W. (1942). "A Text-Book of Bacteriology", 4th ed., p. 450. Heinemann, London.

Hoyle, L. (1948). Monthly Bull. Minist. Hlth, Lond., 7, 114.

Kent, J. F., Bukantz, S. C., and Rein, C. R. (1946). J. Immunol., $53,37$.

Mackie, T. J., and McCartney, J. E. (1948). "A Handbook of Practical Bacteriology". 8th ed., p. 244. Livingstone, Edinburgh.

Mayer, M. M., Eaton, B. B., and Heidelberger, M. (1946). J. Immunol., 53, 31.

Richardson, G. M. (1940). British Journal of Venereal Diseases, 16, 166.

-(1941). Lancet, 2, 696.

Wadsworth, A. B. (1947a). " Standard Methods of the Division of Laboratories and Research of the New York State Department of Health ", 3rd. ed., p. 379. Baillière, Tindall and Cox, London.

(1947b). Ibid., p. 376.

Whillans, D. (1950). J. clin. Path., 3, 56.

Wyler, E. J. (1929). Spec. Rep. Ser. med. Res. Coun., Lond., No. 129. 